研究ノート

\title{
テニス参加者の観戦阻害要因に関する検討
}

一国内 2 大プロトーナメントに着目してー ${ }^{\dagger}$

\author{
霜 島 広 樹* 木 村 和 彦**
}

\section{Barriers to Spectator Behavior among Tennis Participants: Focusing on Two Big Tournaments in Japan ${ }^{\dagger}$}

\author{
Hiroki SHIMOZIMA* and Kazuhiko KIMURA**
}

\begin{abstract}
The purpose of this study was to examine barriers to spectator behavior among tennis participants in order to increase the number of participant spectators in tennis. We focused on two big tennis tournaments in Japan to clarify this.

We extracted barriers to spectator behavior by qualitative methods, and then analyzed the degree of these barriers by statistical methods. As a result, the main findings are summarized as follows:

1) Barriers to spectator behavior among tennis participants consist of "Time", "Distance", "Lack of information", "Absence of cynosure players", "Cost", "Unaccompanied", "Partner", "Child", "TV", "Lack of intention and interest".

2) "Time" is the largest barrier to spectator behavior among tennis participants, so the tactic of changing the time of main events from daytime to nighttime could be effective. Additionally, "Lack of information" and "Cost" were relatively large barriers to spectator behavior in tennis participants, so marketers need to distribute discount tickets that also promote informational purposes.
\end{abstract}

Key words : Barriers, Spectator Behavior, Tennis

1. 緒言

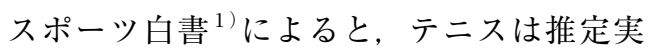
施人口が約 700 万人も存在する普及率の高いス

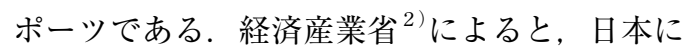
おいてテニスクラブは 1,531 存在しており， ス ポーツ参加, すなわち「するスポーツ」という
視点から見ると，テニスは規模が極めて大きい 種目と言えるだろう.

その一方で，スポーツ観戦という視点からテ ニスを見た場合，テニスは極めて規模の小さい 種目であることが指摘されている ${ }^{3)}$. スポーツ 白書 ${ }^{1)}$ においては, テニスの観客動員数につい ては,そもそも記載の対象とさえされておらず,

\footnotetext{
${ }^{\dagger}$ 原稿受付 2012年 6 月29日 原稿受諾 2012年 8 月14日

*早稲田大学大学院スポーツ科学研究科 ₹202-0021 東京都西東京市東伏見 $2-7-5$

**早稲田大学スポーツ科学学術院７202-0021 東京都西東京市東伏見 3-4-1

${ }^{*}$ Graduate School of Sport Sciences, Waseda University, 2-7-5, Higashifushimi, Nishitokyo, Tokyo, Japan (202-0021)

** Faculty of Sport Sciences, Waseda University, 3-4-1, Higashifushimi, Nishitokyo, Tokyo, Japan (202-0021)
} 
霜島・木村 ${ }^{4)}$ の行った調査においても, 観客動 員数が 2 万人を超える観戦イベントが年間を通 して 2 度しか存在しないといった事実が明らか になっている。霜島 ${ }^{3)}$ は, 「テニスのような参 加人口が極めて多いスポーツにおいては, 参加 者をいかにして観戦者とするかといった方策を とることも有効である」と指摘しており, テニ スを行わないものを観戦へ導くだけでなく，わ が国に存在する数多くのテニス参加者を上手く 観戦者へと誘導していくことも重要であると考 えられる. 佐野 ${ }^{5)}$ は, 「国内で開催される国際 スポーツイベントに多くの観戦者が増加するこ とで, 経済面だけでなく競技の普及や振興の発 展が強く期待されうる」と述べており, テニ スの観戦者を増加させることには，単に経済的 な便益に留まらない, 大きな意味があると考え られる。同じ球技系・個人種目であるゴルフが 2009年度には, 男子·女子・シニアのプロッアー 観客動員数が約 100 万人を数えたことからも, 可能性のあるフィールドとして, 今後のテニス 観戦市場の拡大が望まれる。

スポーツ観戦者に関する研究，すなわちス ポーツ観戦行動に関する研究は, 主にスポーツ 消費者行動の研究領域において多くの関心を集 め, これまでにも多くの科学的知見が蓄積され てきている ${ }^{6)}$. スポーツ消費者とは, 松岡 ${ }^{7)} に$ よると，金銭的コスト（料金など）および非金 銭的コスト（時間・労力など）を費やしてスポー ツを「する」または「見る」という形態で体験 し，身体的および心理的ベネフィットの獲得を 目的としてスポーツを消費する個人である。つ まり，スポーツ観戦者とは，このスポーツ消費 者の定義を「見る」に限定したものであると捉 えることができる．

こういった中で，消費者拡大に関しての戦略 の 1 つとして, 観光などの余暇活動の研究領域 においては, 消費行動への阻害要因への注目が 高まってきている ${ }^{8)}$. Crawford and Godbey ${ }^{9)}$, Crawford, Jackson and Godbey ${ }^{10)}$ は, 阻害要因 は「個人内」,「対人的」,「構造的」という 3 つ の要因から構成されていることを明らかにして
いる. 個人内要因とは, パーソナリティ, レ ジャーに対する態度や価值観, 興味の欠如など 個人の内部に生じる心理傾向のことであり，ま た，対人的要因とは家族や友人など他者との社 会的相互作用から生じるもので，一緒に活動す る相手がいないなどの要因である。 そして，構 造的要因とは，時間や費用の不足，活動環境へ のアクセスの困難さといった主に外的な状況要 因のことである ${ }^{8)}$.

ところで, 前述した個人的要因である「態度」 や「興味」の度合いであるが，スポーツ消費者 行動論においては, 態度は行動への意図（興 味）を，行動への意図は行動を予測する主要因 であり，スポーツやレジャー・レクリエーショ ンの分野の研究でも, その重要性が報告されて いる ${ }^{11)}$.この考え方は, 行動は直接予測される のではなく，行動への意図（行動意図）が予 測変数とされるとした, Fishbein and Ajzen ${ }^{12)}$ による合理的行為理論 (Theory of Reasoned Action：TRA）に起源を成しており，TRAは, この理論をジョギング行動に適用したRiddle ${ }^{13)}$ によって有効性が検証されている.

上記のような, 行動と行動意図との関係性を 踏まえた上で,「個人内」,「対人的」,「構造的」 という行動に対しての阻害要因を捉えなおす と, 行動の阻害要因はまず, 個人内阻害要因で ある「行動意図が低いこと（興味・関心の欠如） が行動に結びつかせない」と, 対人的阻害要因, 構造的阻害要因である「行動意図は高いが，一 緒に活動する相手がいない」，「時間的，金銭的 な余裕がない」の 2 つら構成されると考える ことができる.これを観戦行動に置き換えると， 観戦の阻害要因は,「そもそも, 観戦意図が低 いことが観戦行動に結びつかせない」という個 人内要因と,「観戦意図は高いが, 一緒に観戦 に行く相手がいない」，「観戦意図は高いが，時 間的，金銭的な余裕がない」という対人的，構 造的要因から構成されていると考えることが出 来る.

「観戦行動への意図が低いこと（個人内要因） が原因で，観戦行動に結びつかない」といった 
問題に関しては, 観戦行動の意図を高める様々 な研究がこれまで数多くなされてきており, 研 究の蓄積は着実に進んでいると言える.しかし, 一方で「観戦行動への意図は高いが, 観戦阻害 要因（対人的要因・構造的要因）が原因で, 観 戦行動に結びつかない」といった議論は, これ まで殆どなされてきていない.わが国において, スポーツ観戦に関する, 対人的要因・構造的要 因における阻害要因の先行研究としては, 12歳 以下の子どもを持つ母親のスポーツ観戦者行動 に着目した藤本他 ${ }^{14)}$ が挙げられるものの, 他に 主な研究は管見ながら見られず, 観戦阻害要因 についての理解は，まだあまり進んでいないこ とが司える.

以上より，今後のテニスを始めとするスポー ツ観戦者の拡大においては, 特に, この対人的・ 構造的要因における観戦阻害要因について理解 を深めていく必要があると考えられる.

\section{2. 研 究目的}

本研究は, テニス観戦における観戦阻害要因 に着目をした。 まず, 研究 1 では, テニス参加 者におけるプロテニストーナメントへの観戦 阻害要因を明らかにすることを目的とした。 そ して, 研究 2 では, 観戦意図は高いが観戦には 行かなかったテニス参加者におけるプロテニス トーナメントへの観戦阻害要因, つまり「対人 的要因」と「構造的要因」における観戦阻害要 因に焦点を当て，それらの大きさを量的に検討 することを目的とした。

なお, 本研究においては, スポーツ観戦を「大 会等のスポーツイベントを試合会場で直接観る こと」とし, TVやインターネットなどのメディ アを媒体にした視聴は含めないものとする.

\section{3. 研究 1 : テニス参加者におけるプロテニス トーナメントへの観戦阻害要因}

\section{1 プロテニストーナメントへの観戦阻害}

\section{要因の構成}

研究 1 では, テニス参加者のプロトーナメン トへの観戦阻害要因 (以下, 観戦阻害要因とす
る）を明らかにするために，テニス参加者を対 象にインタビュー調查を行った. インタビュー 調査は, 2010年 5 月 4 日〜 5 日に, 東京都 S区 Tテニスクラブにおけるテニス参加者, そして 埼玉県 $\mathrm{T}$ 市にある $\mathrm{S}$ 公共テニスコートにおける テニス参加者に対して行った. インタビューの 内容は，まず，わが国における代表的な 2 大プ ロテニストーナメントである楽天ジャパンオー プン (旧AIGジャパンオープン), 東レ・パン パシフィックオープンへ観戦に訪れた経験があ るかどうかを尋ね, 観戦経験がなければ, こ れまで観戦に行かなかった理由について質問し た. 取得したデー夕はその場でフィールドノー トに記録した。

インタビュー調査の結果, 74人からデータが 取得できた. 内訳としては，Tテニスクラブに おけるテニス参加者が 60 人, 公共テニスコート でのテニス参加者が14人であった。

\section{2 結果（KJ 法によるテニス観戦阻害要因 の抽出）}

インタビュー調査から得られたデータからプ ロテニストーナメントへの観戦阻害要因の抽

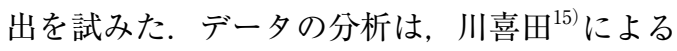
KJ法を用いた，KJ法は，多くの断片的なデー 夕を統合し，核心となる要因を抽出できるとい う点において優れており，この手法はテニス参 加者の観戦阻害要因をうまく抽出・整理できる 方法であると判断した.

まず，インタビューの内容を箇条書きでまと め, テニスへの参加者の, 観戦行動を阻害して いると考えられる要因に関連のある各々の内容 をコード化し，46枚のカードに記入した。 これ を基に, スポーツ経営学を専攻する大学院生と 共に分類, 整理を行った. そして, 全てのカー ドについて内容の近いもの同士を集め，10のグ ループを編成した。 その後, 10のグループに対 し，各々見出しを付けた（表 1 ）.

分析の結果,「大会の開催日時に対し時間が 合わない」という【時間】,「大会会場の距離が 遠い」という【距離】,「大会開催に関する情報 
表 1 KJ 法から抽出された観戦阻害要因

\begin{tabular}{|c|c|}
\hline 観戦阻害要因 & 代表的なコード \\
\hline \multirow{2}{*}{ 時間(10) } & 時間が合わない \\
\hline & 日程が合わない \\
\hline 距離(2) & 会場が遠い \\
\hline \multirow{2}{*}{ 情報不足(2) } & どこでやっているか知らない \\
\hline & 情報が入って来ない \\
\hline \multirow{2}{*}{ 同伴者不在(4) } & 一緒に行く人がいない \\
\hline & 一人で行っても面白くない \\
\hline 注目選手不在 $(9)$ & 知っている選手がいない \\
\hline \multirow{2}{*}{ コスト(5) } & チケットが高い \\
\hline & お金がなかった \\
\hline 配偶者の存在(1) & $\begin{array}{l}\text { 仕事をしてる旦那に対し後ろ } \\
\text { めたい }\end{array}$ \\
\hline \multirow{3}{*}{ 子どもの存在 $(6)$} & 子どもがいるので世話をしな \\
\hline & いといけない \\
\hline & 子どもがいるので縛りがある \\
\hline TV 中継(2) & TV で十分だから \\
\hline 興味・関心の & 興味がないから \\
\hline 欠落 $(5)$ & 観るのが好きじゃないから \\
\hline
\end{tabular}

がない」という【情報不足】，「一緒に行く人が いない」という【同伴者不在】「知っている選 手がいない」という【注目選手不在】,「チケッ トなどが高い」という【コスト】，「配偶者に対 し後ろめたい」という【配偶者の存在】,「子ど もの世話をしなければならない」という【子ど もの存在】,「TV中継で観戦すれば十分」とい う【TV中継】, そもそも観戦に興味・関心がな いという【興味・関心の欠落】といった 10 要因 が, テニス参加者における観戦阻害要因として 抽出された.

\section{3 考察 (研究 1)}

表1で示した結果を, Crawford and Godbey ${ }^{9)}$, Crawford, Jackson and Godbey ${ }^{10)}$ が述べた「個 人内」,「対人的」,「構造的」という観戦阻害要 因の構成へ当てはめて考えてみると，「興味・ 関心の欠落」は「個人内・観戦阻害要因」に該 当し,「同伴者不在」,「配偶者の存在」,「子ど もの存在」は「対人的·観戦阻害要因」, そして, 「時間」, 「距離」,「情報不足」,「注目選手不在」,
「コスト」,「TV中継」は「構造的・観戦阻害要 因」に該当すると考えられる. 分析の結果から, 「注目選手不在」や「TV中継」といったスポー ツ観戦特有とも見られる観戦阻害要因が抽出さ れたことは興味深い結果であった。

研究 2 では, 緒言でも述べたように,「対人 的」,「構造的」における観戦阻害要因に着目し て研究を進めていく.

\section{4. 研究 2 : 観戦阻害要因の検討}

\section{1 研究方法}

研究 2 においては,「対人的要因」,「構造的 要因」における観戦阻害要因に着目し, それら の大きさを量的に検討することを目的とした. よって, 研究 1 で明らかになった10の観戦阻害 要因から「個人内要因」である「興味・関心の 欠落」を除外した 9 の観戦阻害要因を対象に, 研究 2 は行われるものとした.

緒言でも述べたように，「対人的要因」，「構 造的要因」における観戦阻害要因は，「観戦意 図は高いが観戦に行かなかった人」に対し作用 している要因であると考えられる。よって,「対 人的要因」,「構造的要因」における観戦阻害要 因について検討するためには，「観戦意図は高 いが, 観戦に行かなかったサンプル」の構成を

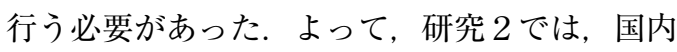
で行われるプロテニストーナメントに対し「観 戦意図は高いが, 観戦に行かなかったサンプル」 を構成することで,「対人的要因」,「構造的要因」 における観戦阻害要因の程度について検討を行 うこととした，研究目的を達成するために，研 究 2 では質問紙調查による統計的な手法を用い た。

質問紙の内容は,「基本的属性」「プロテニ ストーナメント観戦意図」,「プロテニストーナ メント観戦行動」,「プロテニストーナメントへ の観戦阻害要因」の 4 つから構成された。プロ テニストーナメントに関しては, 研究 1 同様に, わが国における代表的なプロテニストーナメン トである「東レ・パンパシフィックオープン」 と「楽天ジャパンオープン」を対象とすること 
とした，基本的属性については，テニス参加者 の属性を把握するために, 性別・年齢・職業に ついて質問した。 そして，プロテニストーナメ ント観戦意図に関しては，「あなたは，東レ。 パンパシフィックオープンや楽天ジャパンオー プンといったテニスのプロトーナメントを, 試 合会場で観戦してみたいと思いますか」といっ た形式で,リッカート法・7段階尺度にて質問 した，加えて，テニストーナメント観戦行動に ついては, 2010年度において東レ・パンパシ フィックオープン, もしくは楽天ジャパンオー プンを，試合会場で観戦したかどうかを質問項 目として設定した.

そして, プロテニストーナメント観戦阻害要 因については, 上記のプロテニストーナメント 観戦行動に関して「観戦には行かなかった」と 回答したサンプルを対象に，質問項目を設定し た. 質問項目は，KJ法にて抽出された10の観 戦阻害要因から, 個人内要因である「興味・関 心の欠落」を除外した 9 つの要因（時間, 距 離, 情報不足, 同伴者不在, コスト, 注目選手 不在, 配偶者の存在, 子どもの存在, TV中継) について質問した. 具体的には,「あなたが今年, 楽天オープン, 並びに東レ・パンパシフィック オープンを会場で観戦しなかった理由として, 以下の質問について各々当てはまる数字に $1 つ$ だけ○をつけて下さい」といった形式で,「時 間が合わなかったから」,「会場が遠いから」,「情 報が入って来なかったから」，「一緒に行く人が いなかったから」、「応援したい選手がいなかっ たから」,「チケットが高いと感じたから」,「観 戦に行くことで, 夫（妻）への後ろめたさを感 じるから」,「子どもの世話があるから」,「TV での観戦で十分だと思ったから」を質問項目と して設定した，そして，「強く当てはまる」か ら「全く当てはまらない」のリッカート法 7 段 階尺度にて，9つの質問項目すべてに対し回答 を求めた。

\section{2 調査期間・調査場所}

調査期間は2010年10月11日〜 11月11日とし

\section{表 2 観戦意図の大きさと観戦行動の関係}

\begin{tabular}{lcc}
\hline & 全サンプル数 & $\begin{array}{c}\text { 観戦に行った } \\
\text { サンプル数 }\end{array}$ \\
\hline 観戦意図 7 & 98 & 46 \\
観戦意図 6 & 66 & 17 \\
観戦意図 5 & 56 & 7 \\
観戦意図 4 & 35 & 0 \\
観戦意図 3 & 9 & 0 \\
観戦意図 2 & 11 & 0 \\
観戦意図 1 & 18 & 0 \\
\hline
\end{tabular}

た.この期間に定めた理由としては, 2010年度. 楽天ジャパンオープンの全日程が終了するのが 2010年10月10日であったということが挙げられ る（東レ・パンパシフィックオープンは 9 月末 に全日程が終了)。調查期間が長くなると, 記 憶も曖昧になる可能性が生じるため, 調查期間 を 1 ケ月と定めた.

また，質問紙の配布場所に関しては，東京都 $\mathrm{S}$ 区の $\mathrm{T}$ テニスクラブ, 埼玉県 $\mathrm{T}$ 市にある $\mathrm{S}$ 公 共コート，そして東京都にある $\mathrm{M}$ 大学のテニス サークル用コートにて，テニス参加者に対し質 問紙の配布を行った。配布場所から，楽天ジャ パンオープン, 東レ・パンパシフィックオープ ンが行われる「東京都・有明テニスの森」まで の所要時間は, いずれも時間にして 1 時間から 1 時間半程度であった.

配布に関しては，筆者の自己紹介をした上で 直接手渡しをした，回答はその場で行ってもら い, 記入終了後は速やかに回収を行った。記入 に関しての疑問点，記入漏れなどの不都合が生 じた場合は，筆者がその場で対応した，回答者 の都合で, どうしてもその場での記入が難しい ものに関しては, 後日回収を行った.

\section{3 結果}

\section{3.1 観戦意図の高いサンプルの抽出}

調査の結果, 取得されたサンプル数は304で あり，有効回答数は293であった（テニスクラ ブ170, 公共テニスコート 75 , 大学テニスサー クル48). 研究目的でも示したように, 研究 2 では「観戦意図が高いが観戦に行かなかった参 
表 3 「観戦意図 5 以上で観戦に行かなかったサンプル」の基本的属性

\begin{tabular}{|c|c|c|c|c|c|c|}
\hline \multirow{2}{*}{ 性別 } & & $\mathrm{N}$ & $\%$ & & $\mathrm{~N}$ & $\%$ \\
\hline & \multicolumn{6}{|c|}{ 職業 } \\
\hline & 男性 & 69 & 47.3 & 会社員 · 公務員 & 39 & 26.7 \\
\hline & 女性 & 77 & 52.7 & 管理職·経営 & 3 & 2.1 \\
\hline 年齢 & & & & 自営業 & 6 & 4.1 \\
\hline & 10代 & 15 & 10.3 & 自由業 & 2 & 1.4 \\
\hline & 20代 & 42 & 28.8 & 主婦専業 & 26 & 17.8 \\
\hline & 30代 & 26 & 17.8 & 学生 & 32 & 21.9 \\
\hline & 40代 & 25 & 17.1 & 中高生 & 8 & 5.5 \\
\hline & 50代 & 18 & 12.3 & その他 & 30 & 20.5 \\
\hline & 60代以上 & 20 & 10.7 & & & \\
\hline
\end{tabular}

加者」を対象に検討を行うことから，まず，観 戦意図の高いサンプルの抽出を行うこととし た。

取得された293のサンプルにおいて, プロトー ナメントへの観戦意図の高さと観戦・非観戦の 割合を表にしてまとめた（表 2 ). 結果, 観戦 意図が 1 から 4 のサンプルにおいて観戦へ行っ たサンプルはなく, 観戦意図 5 から初めて, 観 戦へ行ったサンプルが出現することが確認され た.このことから, 研究 2 では観戦意図が 5 以 上のサンプルを「観戦意図が高いサンプル」と し，分析を進めることとした．統計的分析には SPSS17.0を用いた。

\section{3. 2 観戦意図の高い非観戦者サンプルの基 本的属性}

「観戦意図は高いが観戦に行かなかったサン プル」を抽出するために, まず, 取得されたデー タから，2010年度にプロトーナメントへの観戦 行動があったサンプルを全て除外した上で，プ ロトーナメントへの観戦意図が 5 未満であった サンプルも全て除外した。 さらに, 対象とされ たサンプルから, 観戦阻害要因に関する項目が 未記入であったものを除外した. 結果, 得られ たサンプルは146であった. サンプルの基本的 属性を集計し, 表了に示した。

性別に関しては, 男女共ほぼ同数となった。 年齢に関しては，20代が若干多かったが全体的 に大きな偏りはなかった。
表 4 観戦阻害要因に関する項目の平均値と標準 偏差

\begin{tabular}{lcc}
\hline 観戦阻害要因 & Mean & SD \\
\hline 時間 & 5.22 & 2.04 \\
距離 & 3.41 & 2.04 \\
情報不足 & 3.14 & 2.22 \\
同伴者不在 & 2.91 & 2.06 \\
注目選手不在 & 2.38 & 1.60 \\
コスト & 3.29 & 2.07 \\
配偶者の存在 & 1.41 & 1.18 \\
子どもの存在 & 1.65 & 1.55 \\
TV中継 & 3.25 & 1.97 \\
\hline
\end{tabular}

続いて, 観戦阻害要因に関する 9 項目の, 各々 の平均值と標準偏差を算出した（表4).

最も平均值が大きかったのが,「時間」であ り,「距離」,「コスト」,「TV中継」,「情報不足」, 「同伴者不在」と続いた.「配偶者の存在」,「子 どもの存在」は共に平均值は低かった.

\section{3. 3 「会社員·公務員」,「専業主婦」,「学生」 ごとの観戦阻害要因の大きさ}

続いて, 観戦阻害要因の量的な検討をより深 めるために,「会社員・公務員」,「専業主婦」「学 生」ごとの観戦阻害要因の程度を検討した. 会 社員・公務員, 専業主婦, 学生を分析の対象と した理由としては, 表 3からも判断できるよう に, これらのサンプル数は全体の大部分を占め ていたことが挙げられる.このことから, 会社 
表 5 「会社員・公務員」,「専業主婦」,「学生」ごとの基本的属性

\begin{tabular}{|c|c|c|c|c|c|c|c|}
\hline & & \multicolumn{2}{|c|}{ 会社員·公務員 } & \multicolumn{2}{|c|}{ 専業主婦 } & \multicolumn{2}{|c|}{ 学生 } \\
\hline & & $\mathrm{N}$ & $\%$ & $\mathrm{~N}$ & $\%$ & $\mathrm{~N}$ & $\%$ \\
\hline \multicolumn{8}{|l|}{ 性別 } \\
\hline & 男性 & 18 & 46.2 & 0 & 0 & 21 & 67.8 \\
\hline & 女性 & 21 & 53.8 & 26 & 100.0 & 10 & 32.3 \\
\hline \multicolumn{8}{|l|}{ 年齢 } \\
\hline & 10 代 & 0 & 0 & 0 & 0 & 3 & 9.7 \\
\hline & 20 代 & 8 & 20.5 & 0 & 0 & 28 & 90.3 \\
\hline & 30 代 & 18 & 46.2 & 1 & 3.8 & 0 & 0 \\
\hline & 40代 & 9 & 23.1 & 8 & 30.8 & 0 & 0 \\
\hline & 50代 & 3 & 7.7 & 10 & 38.5 & 0 & 0 \\
\hline & 60代以上 & 1 & 2.6 & 7 & 26.9 & 0 & 0 \\
\hline
\end{tabular}

表 6 「会社員・公務員」,「専業主婦」「学生」ごとの観戦阻害要因

\begin{tabular}{|c|c|c|c|c|c|c|c|c|c|}
\hline \multirow{2}{*}{ 観戦阻害要因 } & \multicolumn{2}{|c|}{ (1)会社員·公務員 } & \multicolumn{2}{|c|}{ (2)専業主婦 } & \multicolumn{2}{|c|}{ (3)学生 } & \multicolumn{2}{|c|}{ 分散分析 } & \multirow{2}{*}{ 多重比較結果 } \\
\hline & Mean & $\mathrm{SD}$ & Mean & $\mathrm{SD}$ & Mean & $\mathrm{SD}$ & $(\mathrm{F})$ & $(\mathrm{p})$ & \\
\hline 時間 & 5.0 & 2.15 & 5.0 & 1.95 & 5.7 & 2.02 & 1.33 & .270 & \\
\hline 距離 & 3.4 & 1.88 & 3.5 & 1.99 & 3.8 & 2.27 & .329 & .721 & \\
\hline 情報不足 & 3.4 & 2.15 & 2.2 & 1.67 & 4.5 & 2.39 & 7.77 & .001 & (1) $>$ (2), (3) $>$ (2) \\
\hline 同伴者不在 & 3.2 & 2.23 & 2.5 & 1.73 & 3.4 & 2.32 & 1.18 & .313 & \\
\hline 注目選手不在 & 2.5 & 1.64 & 2.2 & 1.55 & 2.7 & 1.92 & .433 & .650 & \\
\hline コスト & 3.1 & 2.08 & 3.4 & 1.74 & 4.0 & 2.32 & 1.98 & .144 & \\
\hline 配偶者の存在 & 1.4 & 1.04 & 1.7 & 1.76 & 1.5 & 1.29 & .525 & .593 & \\
\hline 子どもの存在 & 1.3 & 1.11 & 2.7 & 2.46 & 1.5 & 1.15 & 6.78 & .002 & (2) $>$ (1), (2) $>$ (3) \\
\hline TV中継 & 3.6 & 1.86 & 3.3 & 2.13 & 3.4 & 2.00 & .201 & .818 & \\
\hline
\end{tabular}

員・公務員, 専業主婦, 学生は, わが国のテニ ス参加者において大きな割合を占めていると考 え,これらに着目して分析を進めることとした. 会社員, 専業主婦, 学生におけるサンプルの基 本的属性を表 5 に示した.

そして, 観戦阻害要因に関する会社員・公務 員, 専業主婦, 学生ごとの差異を検討するため に, 石村・石村 ${ }^{16)}$ を参考に観戦阻害要因に関す る 9 項目について, 1 元配置分散分析による統 計的検定を行った. そして, 分散分析の結果に おいて統計的有意性が確認されたものについて は, 下位検定としてTukey法による多重比較を 行った（表6).

分析の結果, 会社員・公務員において最も平 均值の高かった観戦阻害要因は「時間」であり,
次に「TV中継」,「距離」,「情報不足」,「同伴 者不在」と続いた. また, 専業主婦においては「時 間」が最も高く, 次に「距離」,「コスト」と続 いた. そして, 学生においては「時間」が最も 高く, 続いて「情報不足」,「コスト」,「距離」 の順に高かった.

分散分析の結果「情報不足」と「子どもの存 在」の平均值において, 会社員・公務員, 専業 主婦, 学生の間に, $1 \%$ 水準で統計的有意差が 確認された。 そして, 多重比較の結果から「情 報不足」に関しては, 会社員・公務員と学生の 平均值が, 専業主婦より高いことが統計的に示 された。また「子どもの存在」に関しては, 専 業主婦の平均值が, 会社員・公務員と学生を上 回る結果となった. 


\section{4 考察（研究 2)}

研究 2 においては,「構造的要因」,「対人的 要因」における観戦阻害要因に着目し，それら の大きさを量的に検討することを目的とした. そこで, 研究 1 で明らかになった10の観戦阻害 要因から,「個人内要因」である「興味・関心 の欠落」を除外した 9 の観戦阻害要因を対象に 検討を行った.

まず, 最も平均值が大きかった観戦阻害要因 は,「時間」であった。「時間」に関しては, 会 社員・公務員, 専業主婦, 学生においても, そ れぞれ高い平均值となり，このことから観戦意 図の高いテニス参加者にとって，「時間が合わ ない」ことは大きな観戦阻害要因の 1 つであ り, 今後観戦者を増加させるためには, この部 分を改善する必要性が第 1 に考えられる.わが 国において，サッカーなどの観戦者人口の多い スポーツにおいては, 夕方から夜にかけてゲー ムが開催されることが多いのに対し，テニスの 大会は, 基本的に平日の日中を中心にゲームが 行われる（注 1 ）。平日の日中は, 仕事・授業 など多くの人にとって都合が悪い可能性が高い と考えられ，これが「時間」という観戦阻害要 因の大きさが高い原因になっていると推察され る.

楽天ジャパンオープンでは, 実際には夜間ま でゲームが行われていることも多いが, その事 実を認識していないテニス参加者も多い可能性 が考えられる。 また，わが国におけるプロテニ ストーナメントでは, 注目選手が出場する試合 が昼から夕方前に行われることが多く（注 2), 夜間にメインイベントが行われることは殆どな い. USオープンなどを始めとするグランドス ラム大会は, メインイベントを夜間に行うこと が多く(注 3), そういった戦略も取り入れる 必要性があると言えよう。

観戦阻害要因において, 続いて大きかったの が,「距離」であった。「距離」に関しては, 会 社員・公務員, 専業主婦, 学生ごとの分析にお いても, 全体的に平均值が $3 \sim 4$ という中程度
の值となった. 河合・平田 ${ }^{17)}$ による研究でも, 移動距離と観戦回数には負の相関関係があるこ とが指摘されていることから，これは妥当な結 果であったと考えられる。今回の研究では，質 問紙の配布場所から, 楽天ジャパンオープン, 東レ・パンパシフィックオープンが行われる 「東京都・有明テニスの森」までの所要時間は, いずれも時間にして 1 時間から 1 時間半程度で あったが, サンプリングを首都圈外から行うこ とで，違った結果が導かれる可能性もある．わ が国における代表的な 2 大プロテニストーナメ ントは, いずれも東京・有明で行われるため, 首都圈以外の観戦者を増やすためには, 首都圈 以外でも同様の大会を行い，また大会を行える ような環境を整備することも必要であろう。な お，本研究においては，テニス参加者の各々の 居住地から有明テニスの森までの, 正確な移動 時間を踏まえた分析は行うことができなかった ので, この点に関しては今後の課題と言える.

続いて,「情報不足」に関しては, 全体平均 では3.1であったが, 会社員·公務員, 専業主婦, 学生ごとの分析では, 学生が4.5と他に比べて 大きく, 統計的有意差も確認される結果となっ た.ここから，大学でテニスを行う学生は，プ ロテニストーナメントに関する情報収集が上手 く行えていない可能性が考えられる，学生の観 戦者を増やすためには, この点の改善が必要で あると言えよう。

また,「コスト」に関しては, 全体平均では「時 間」,「距離」に続く，3番目に大きな観戦阻害 要因であった. 金銭的コストの大きさは, 多く の先行研究からも観戦行動へ負の影響を与える ことが示唆されており，大会主催者がいかにチ ケット等の価格をコントロールするかが重要と 言えるだろう。会社員・公務員, 専業主婦, 学 生ごとの分析において, 統計的有意差は確認さ れなかったものの, 学生の值が4.0と他 2 つに 比べかなり高い数值を示していたことから,「コ スト」は学生にとって，1つの大きな観戦阻害 要因となっている可能性が瞀える.上述した「情 報」も踏まえて, 学生テニスサークルや部活に 
対し, 団体レベルでの割引券の配布を行うなど, 情報の提供も兼ねたコストに対する戦略を考え ることが, 観戦者の拡大において有効であると 思われる。

また「TV中継」の大きさは「距離」同様, 全体平均が 3.25 と程度の值であった。この結 果から，TV中継も観戦阻害要因として考えら れると言える。しかしながら，TV中継は観戦 者の拡大において，テニス参加者以外の層を取 り込める可能性があるといった点で重要である と考えられる.よって，テニス参加者に対して は, TV観戦とスタジアム観戦の与える便益の 違いや, スタジアム観戦特有の魅力というもの を明らかにし，それをアピールしていくことが 必要であろう。

一方で, 対人的要因である「配偶者の存在」 や「子どもの存在」に関しては, 全体平均值が 2 未満となり, わが国におけるテニス参加者に とって大きな阻害要因となっているとは言い難 い結果となった。 しかしながら, 会社員・公務 員, 専業主婦, 学生ごとの検討では, 専業主婦 において「子どもの存在」の平均值が, 会社員・ 公務員, 学生に比べ高い統計的有意差が確認さ れた。このことから, 藤本他 ${ }^{14)}$ の研究同様, 主 婦にとって子どもの存在は 1 つの観戦阻害要因 となりうる可能性が考えられる. 研究 2 におけ る「専業主婦」のサンプリングにおいては, 子 どもの有無までは検討しておらず, 藤本他 ${ }^{14)} の$ 研究のように,「12歳以下の子どもを持つ母親」 に限定してサンプリングを行った場合,「子ど もの存在」が, より大きな観戦阻害要因になる 可能性は十分に考えられる. 観戦における主婦 層の拡大を考えるのであれば, 託児所の併設な ど，子どもを持った母親への対応も検討してい く必要があると言えよう. 同じ対人的要因であ る「同伴者不在」に関しては, 全体平均が 2.9, 会社員・公務員と学生における平均值がそれぞ れ3.4という結果になり,「配偶者の存在」や「子 どもの存在」と比べると大きな值であった.

最後に,「注目選手不在」であるが, 全体と して 3 以下の平均値となり, 観戦阻害要因とし
てはあまり大きくないことが明らかとなった. 2012年現在において，世界ランキング・トップ 20入りを果たした錦織圭選手などの影響も，こ の結果に繋がっているかと推察される.

\section{5. 結論（今後の課題・研究の限界）}

本研究では, テニス参加者の観戦阻害要因を 抽出し，それらをより詳細に検討していくこと を通して，テニスにおける観戦者を拡大するた めの研究の蓄積に貢献することができたが, 同 時にいくつかの限界を浮き上がらせた.

まず，サンプリングの問題が挙げられる．本 研究ではテニスクラブ, 公共テニスコート, 学 生テニスサークルを対象にサンプリングを行っ たが，わが国においては，これら以外にも当然 テニス参加スタイルは存在しており, その点を 踏まえて研究は継続される必要がある.

また, 本研究ではインタビュー調査から観戦 阻害要因を抽出し, その後, 抽出された観戦阻 害要因を項目化して質問紙を作成した。しか し, 質問項目作成において, 各観戦阻害要因の 具体的な因子構造までは検討を行わなかった. 観戦阻害要因について正確な検討を行うために は，因子構造に関する詳細な検討が必要と考え られ,この点は今後の研究課題と言えるだろう.

最後に, 本研究ではテニス参加者におけるテ ニス観戦への阻害要因を検討したが, 本研究で 得られた知見は, ゴルフ, バドミントン，そし て卓球などといった, 参加人口の多い個人ス ポーツにも応用可能であると考えられる，ただ し, 各スポーツにおける背景の違いなどから， 本研究とは相違点も存在する可能性があること から, ゴルフ, バドミントン, そして卓球など のスポーツにおいても，本研究と同様の検討が 今後望まれると言える。

（注 1 ）楽天ジャパンオープンテニス, 東レ・パン パシフィックオープンテニスは通常, 月曜から 日曜までの約 1 週間かけて行われ, 2010・2011 年度の楽天ジャパンオープンでは， 7 日間のう ち5 日間が平日の開催であり, 開始時刻は 10 時 
〜 12時の間であった ${ }^{1819)}$. 一方で, 2011年度の サッカーJリーグの試合に着目すると, 試合の開 催日時は平日の水曜日, 土日・祝日のいずれか であり, 平日開催の場合は夜 $19 ： 00$ 前後から全 ての試合が開始された ${ }^{20)}$.

（注２）2010年度・ジャパンオープン大会 2 日目（火 曜日）のセンターコートにおいて, 男子の試合 は12時開始であり, 伊藤竜馬VSアンディー・ロ ディック, 錦織圭VSビクトル・トロイッキ, ラ ファエル・ナダルVSサンティゴ・ギラルド, ヤ ルコ・ニエルミネンVSジョーウィルフリード . ツオンガの順で試合が行われた. 注目カードと 考えられる，2010年10月に日本ランキング 1 位 であった錦織圭の試合は, 第 2 試合であり, 当 時世界ランキング 1 位であったラファエル・ナ ダルの試合は第 3 試合であった。

（注 3）2012年現在において, グランドスラム大会 である全米オープン, 全豪オープンなどはデイ セッション, ナイトセッションとチケットの種 類が分かれて販売がなされている．例えば 2012 年度全豪オープンにおいて, ナイトセッション のロッド・レーバーアリーナ（メインコート） での男子の試合は, 大会 1 日目が「ロジャーフェ デラーVSアレクサンドル・クドリャフッェフ」, 2 日目が「セドリック マルセル・ステッベVSレ イトン・ヒューイット」, 3 日目が「サム・クエリー VSバーナード・トミック」, 4 日目が「レイトン ・ヒューイットVSアンディ・ロディック」, 5 日 目が「アレクサンドル・ドルゴポロフVSバーナー ド・トミック」, 6 日目が「ミロシュ・ラオニッチ VSレイトン・ヒューイット」となっており，大 会開催国であるオーストラリア出身のレイトン . ヒューイットやバーナード・トミックなどがナ イトセッションの試合に多く登場している ${ }^{21)}$.

\section{参 考 文 献}

1) SSF笹川スポーツ財団；スポーツ白書2011, SSF笹川スポーツ財団, 2010.

2 ) 経済産業省; 平成16年度特定サービス産業実態 調 查, http : //www.meti.go.jp/statistics/tyo/ tokusabizi/result-2/h16.html, 2012年 6 月閲覧.

3 ）霜島広樹; テニス参加動機が観戦意図へ与 える影響に関する研究, テニスの科学, Vol.20, pp.78-79, 2011.

4 ）霜島広樹, 木村和彦 ; テニス実施者の観戦行動
に関する研究（その1）：スポーツ観戦行動に おける文献レビューから, 日本体育スポーツ経 営学会大会号, Vol.33, pp.47-48, 2010.

5 ）佐野昌行; 国際スポーツイベント観戦者の 基礎的特性に関する研究, 日本体育大学紀要, Vol.36, No.2, pp.231-248, 2007.

6 ) 隅野美砂輝, 原田宗彦 ; スポーツ観戦者行動に おける感情に関する研究動向, スポーツ産業学 研究, Vol.13, No.2, pp.1-11, 2003.

7 ) 松岡宏高; スポーツマネジメントの概念の再 検討, スポーツマネジメント研究, Vol.2, pp.3345, 2010.

8 ）林幸史; 観光行動の促進要因と阻害要因: JGSS-2010のデー夕を用いて, 日本版総合的社 会調查共同研究拠点研究論文集, Vol.11, 2011.

9 ) Crawford, D.W. and Godbey, G. ; Reconceptualizing barriers to family leisure, Leisure Science, Vol.9, No.2, pp.119-127, 1987.

10) Crawford, D.W., et al. ; A hierarchical model of leisure constraints, Leisure Science, Vol.13, No.4, pp.309-320, 1991.

11) Ajzen, I. and Driver, B.L. ; Application of the theory of planned behavior to leisure choice, Journal of Leisure Research, Vol.24, pp.207224, 1992.

12) Fishbein, M. and Ajzen, I. ; Belief, attitude, intension, and behavior: An introduction to theory and research, Reading MA, AdditionWesley, 1975.

13) Riddle, P.K. ; Attitudes, beliefs, behavioral intentions, and behaviors of women and men toward regular Jogging, Research Quarterly for Exercise and Sport, Vol.51, No.4, pp.663674, 1980.

14）藤本淳也, 他 ; 女性のスポーツ参与阻害要因に 関する研究 II : 12歳以下の子どもを持つ母親 のスポーツ観戦者行動について, 大阪体育大学 紀要, Vol.36, pp.84-94, 2005.

15）川喜田二郎；発想法：創造性開発のために, 中 央公論新社, 1967.

16）石村貞夫，石村光資郎；SPSSによる分散分析 と多重比較の手順, 東京図書, 1997.

17）河合慎祐, 平田竹男； Jリーグの観客数に影響 を与える要因に関する研究, スポーツ産業学研 究, Vol.18, No.2, pp.11-20, 2008. 
18）楽天ジャパンオープンテニスチャンピオン シップス2010公式ホームページ ; http：// rakutenopen.rakuten.co.jp/2010/index.html, 2012年 1 月閲覧.

19）楽天ジャパンオープンテニスチャンピオン シップス2011公式ホームページ; http：// rakutenopen.rakuten.co.jp/, 2012年 1 月閲覧.

20）Jリーグ公式ホームページ； http：//www. j-league.or.jp, 2012年 1 月閲覧.

21）全豪オープン2012公式ホームページ； http： //www.australianopen.com/en_AU/index. html, 2012年 1 月閲覧. 